\title{
KEBIJAKAN PENGGUNAAN DRONE DAN IMPLEMENTASI PADA KEMENTERIAN LINGKUNGAN HIDUP DAN KEHUTANAN
}

\section{(Drone Use Policy and Implementation At The Ministry Of Environment And Forestry)}

Gamin

Pusat Pendidikan dan Pelatihan Sumber Daya Manusia Kementerian Lingkungan Hidup dan Kehutanan, Jl. Mayjen Ishak Juarsa Kotak Pos 141, Gunung Batu, Bogor Barat, Kota Bogor, Kode Pos 16118, Indonesia; e-mail: gamingessa@gmail.com

Diterima 8 Oktober 2021, direvisi 24 November 2021, disetujui 25 November 2021

\begin{abstract}
There is a lot of literature related to the use of drones, including evidence implementation framework Grindle (1980) in the Rawa Tripa-Aceh court, but the implementation of this policy needs to be explored specifically at the Ministry of Environment and Forestry. This study aims to examine this. Data were collected through literature studies, interviews, and observations to be analyzed using a policy. The findings of the policy content are: the drone policy has positive benefits for validity and legality, as well as authority, but flying permits have the potential to be negative. The degree of change is quite good even though the registration of drones and drone pilots has not been carried out. In the implementation environment, it was found that the central level was quite responsive even though the work unit had not. Competency improvement has been carried out although it is limited to drone pilots. The drone pilot training materials have not met the certification requirements. Research recommendations are: need coordination in drone operation, need guidelines for using drones, need drone registration and drone pilot certification, need competency development designs for drone users and need additional aeronautical knowledge on drone pilot competency development.
\end{abstract}

Keywords: Policy, content analysis, drone, impact.

\begin{abstract}
ABSTRAK
Banyak literatur terkait penggunaan drone, termasuk pembuktian di pengadilan kasus Rawa Tripa-Aceh, namun perlu didalami implementasi kebijakan tersebut secara khusus pada Kementerian Lingkungan Hidup dan Kehutanan. Penelitian ini bertujuan mencermati hal tersebut. Data dikumpulkan melalui studi literatur, wawancara, dan observasi untuk dianalisis menggunakan kerangka implementasi kerangka kebijakan Grindle (1980). Temuan isi kebijakan adalah: kebijakan drone bermanfaat positif bagi validitas dan legalitas, serta otoritas, namun perizinan terbang berpotensi negatif. Derajat perubahan cukup baik meski pendaftaran drone dan pilot drone belum dilakukan. Pada lingkungan implementasi ditemukan bahwa level pusat cukup tanggap meski satuan kerja belum. Peningkatan kompetensi telah dilakukan meski terbatas untuk pilot drone. Materi pelatihan pilot drone belum memenuhi syarat sertifikasi. Rekomendasi penelitian adalah: perlu koordinasi dalam pengoperasian drone, perlu pedoman penggunaan drone, perlu registrasi drone dan sertifikasi pilot drone, perlu desain pengembangan kompetensi untuk pengguna drone, dan perlu penambahan pengetahuan aeronautika pada pengembangan kompetensi pilot drone.
\end{abstract}

Kata kunci: Kebijakan, analisis isi, drone, dampak. 


\section{PENDAHULUAN}

Diterbitkannya Peraturan Menteri Perhubungan Nomor 37 Tahun 2020 (PM.37/2020) tentang Pengoperasian Pesawat Udara Tanpa Awak (PUTA) adalah sebagai upaya pemerintah RI untuk mengendalikan penggunaan pesawat udara kecil tanpa awak atau dikenal dengan sebutan drone. Pengaturan ini berubah secara dinamis mengingat perkembangan penggunaan drone pada era teknologi 4.0 semakin dinamis peningkatannya ((FDS, 2019); (Kardasz et al., 2016); (Andyono, 2020); (Pustek, 2020)). Peraturan sebelum PM.37/2020 adalah PM.47 tahun 2016, perubahan PM.180 tahun 2015, dan PM.90 tahun 2015.

Implementasi kebijakan bertugas untuk membangun suatu jalur yang memungkinkan tujuan suatu kebijakan publik dapat terwujud sebagai suatu hasil (output) dan dampak (outcomes) dari aktivitas pemerintah (Grindle, 1980). Implementasi kebijakan penggunaan drone di beberapa kementerian/lembaga telah dilakukan dan dikaji (Eko Prasetyo, 2020) di Kabupaten Kulonprogo, (Yoedtadi, 2019) meneliti pada bidang jurnalistik). Penelitian lain (Ustidivanissa, et al., 2017) mencermati aspek judiris terhadap keselamatan penerbangan di Indonesia. Implementasi pengoperasian PUTA dengan aplikasi berbasis telepon seluler diteliti oleh (Syahbani, 2020). Penelitian drone untuk memonitor perubahan vegetasi dilakukan (Sankey et al., 2019). Di Kementerian Lingkungan Hidup dan Kehutanan (KLHK) penggunaan data drone dalam memastikan lokasi kebakaran di Rawa Tripa-Aceh membantu dalam pengambilan putusan hukum terhadap kerugian negara (Putra et al., 2014). Peraturan penggunaan PUTA dari Kementerian Perhubungan telah mengalami beberapa kali perubahan dengan PM.37/2020 sebagai perubahan terakhir. Sementara peraturan Menteri LHK terkait hal tersebut dilansir pada P.16/2018. Setelah pembaharuan kebijakan-kebijakan tersebut belum diketemukan catatan ilmiah implementasi kebijakan penggunaan drone khususnya pada lingkup KLHK.

Fakta masih terjadinya ketidak-taatan terhadap peraturan penggunaan drone (Yeodtadi, 2019; Hutauruk, 2021) jika tidak segera diketemukan penyebab dan langkah mengantisipasinya akan kontra produktif dengan pekerjaan KLHK diantaranya dalam bidang penegakan hukum. Kontra produktif yang dimaksud adalah data drone yang akan digunakan untuk pembuktian pelanggaran hukum kehutanan dan lingkungan dapat batal pembuktiannya ketika proses pengoperasian drone sendiri melanggar hukum penggunaan ruang udara.

Kecenderungan penggunaan drone yang meningkat tajam pada KLHK, potensi bahaya yang ditimbulkannya, pelanggaran yang ada, catatan dan saran Yoedtadi (2019), serta dinamika peraturan Menteri Perhubungan terkait PUTA, maka masalah yang dapat diidentifikasi adalah belum optimalnya pelaksanaan kebijakan penggunaan drone di KLHK. Bagaimana dengan keberadaan PermenLHK No.P.16/ MenLHK/Setjen/KKL. 1/2018 (P16/2018) tentang Pengoperasian PUTA Lingkup KLHK ini? Terdapat dua variabel besar yang mempengaruhi keberhasilan implementasi kebijakan yakni: isi kebijakan dan lingkungan kebijakan (Grindle, 1980).

Penelitian bertujuan menemukan fakta implementasi kebijakan penggunaan drone pada Kementerian LHK dengan menganalisis faktor isi kebijakan dan lingkungan implementasinya untuk memformulasikan rekomendasi guna mendorong implementasi kebijakan di KLHK selanjutnya. Oleh karena itu ada tiga tujuan dalam penelitian ini, yakni: 1). Mengidentifikasi potensi penggunaan PUTA di KLHK dan permasalahanya, 2). Menganalisis isi kebijakan pendukungnya, dan 3). Memformulasikan rekomendasi guna mendorong implementasi kebijakan penggunaan PUTA agar dapat mengoperasikan dengan aman dan efektif. 


\section{METODE PENELITIAN}

\section{A. Tempat dan Waktu Penelitian}

Penelitian dilaksanakan di Kementerian Lingkungan Hidup dan Kehutanan khususnya di Pusat Keteknikan Kehutanan dan Lingkungan serta Pusat Diklat SDM Lingkungan Hidup dan Kehutanan, untuk lingkup Pusat, dan Balai Taman Nasional Bantimurung Bulusaraung di Sulawesi Selatan untuk lingkup satuan kerja di daerah. Penelitian dilakukan dalam kurun waktu Juli hingga September tahun 2020, masa transisi PM.37/2020 yang terbit 8 Juni 2020 .

\section{B. Metode Pengumpulan Data}

Penelitian ini dilaksanakan dengan menggunakan metode deskriptif dengan pendekatan kualitatif. Kerangka teoritik versi Marilee S. Grindle (1980) digunakan untuk menelaah implementasikebijakan penggunaan drone di KLHK, khususnya dua faktor yang mempengaruhi implementasi kebijakan yaitu faktor isi kebijakan (content of policy) dengan 6 (enam) indikator dan lingkungan implementasi (context of implementation) dengan 3 (tiga) indikator (Gambar 1).
Untuk menjawab pengaruh faktor isi kebijakan dan faktor lingkungan terhadap implementasi kebijakan penggunaan drone, penulis mengumpulkan data melalui wawancara mendalam (indeepth interview atau komunikasi personal), studi dokumen (desk study), dan observasi. Wawancara dilakukan terhadap informan internal KLHK maupun eksternal di luar KLHK. Pada lingkup internal, informan kunci di KLHK adalah Kepala Pusat Keteknikan (Pustek) Kehutanan dan Lingkungan, sebagai Koordinator Pengendali PUTA di KLHK beserta staf terkait. Pada Direktorat Inventarisasi dan Pemantauan Sumber Daya Hutan (DitIPSDH) diwawancarai Kepala Sub Direktorat Pemantauan Sumber Daya Hutan, dan Analis Data Pemantauan Sumber Daya Hutan Tingkat Nasional. Terkait respon KLHK terhadap kebijakan penggunaan drone ini, penulis juga memperoleh informasi dari pejabat senior KLHK yang membidangi Data Spasial dan Penginderaan Jauh. Informasi dari Pusat Diklat SDM LHK diperoleh melalui studi dokumen, dan observasi langsung pada kegiatan webinar dan pelatihan terkait

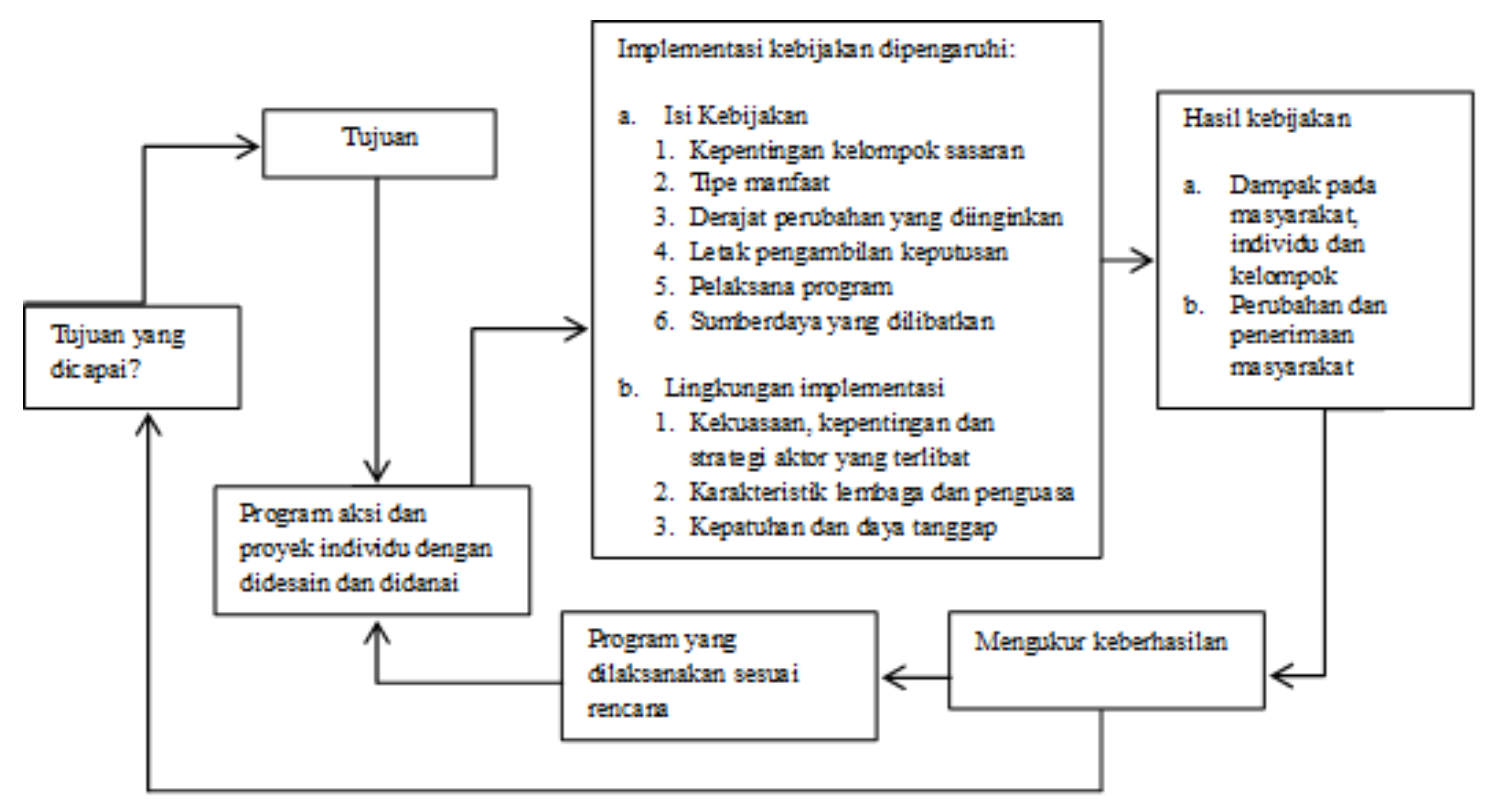

Sumber (Source): (Grindle, 1980)

Gambar 1. Faktor yang Mempengaruhi Implementasi Kebijakan

Figure 1. Factors Affecting Policy Implementation 
drone. Konfirmasi implementasi kebijakan penggunaan drone di tingkat Satuan Kerja (Satker) diwawancarai petugas terkait di Balai Taman Nasional Bantimurung Bulusaraung (TN Babul) di Sulawesi Selatan.

Informan kunci pihak eksternal pada level pusat adalah Paban II Puan SpotdirgaKasau/Dinas Potensi Kedirgantaraan Markas Besar TNI AU /Ketua Bidang Sertifikasi Federasi Aero Sport Indonesia (FASI). Selain itu, ditemui juga Kepala Bidang Registrasi dan Sertifikasi Ditjen Perhubungan Udara Kementerian Perhubungan, Kepala Sub Divisi Operasi Airnav Indonesia, Asosiasi Pilot Drone Indonesia (APDI), serta praktisi/ pilot drone.

Informan eksternal pada tingkat komunitas drone di Makassar juga diwawancara untuk menguatkan informasi terkait pengetahuan tentang peraturan penerbangan drone dan ketentuan hukumnya, serta prosedur yang dilakukan untuk menerbangkan drone di lokasi studi. Komunitas yang ditemui tergabung dalam APDI Makassar, FASI Makassar, dan Dà-Jiāng Innovations (DJI) Chapter Makassar. Selain itu ditemui pula pengguna yang berprofesi sebagai surveyor pemetaan di Balai Pemantapan Kawasan Hutan, dan Pengendali Ekosistem Hutan di Balai Pengelolaan Hutan Produksi di Makassar.

\section{Metode Pengolahan Data}

Data penelitian diolah dengan mengelompokkan menurut indikator isi kebijakan dan lingkungan implementasi (Grindle, 1980). Faktor isi kebijakan (content of policy) meliputi 6 (enam) indikator yakni: 1) kepentingan kelompok sasaran, 2) tipe manfaat, 3) derajat perubahan yang diinginkan, 4) letak pengambilan keputusan, 5) pelaksana program, dan 6) sumber daya yang dilibatkan.

Faktor lingkungan implementasi (context of implementation) terdiri 3 (tiga) indikator yakni: 1) kekuasaan, kepentingan, dan strategi aktor yang terlibat, 2) karakteristik lembaga dan penguasa, serta 3) kepatuhan dan daya tanggap. Kepentingan kelompok sasaran dicermati dari isi pasal demi pasal peraturan yang dikaji dan dianalisis berdasarkan kriteria kelestarian hutan yakni indikator ekologi, sosial, dan ekonomi.

\section{HASIL DAN PEMBAHASAN}

\section{A. Identifikasi Potensi Penggunaan PUTA di KLHK dan Permasalahannya}

Penggunaan drone di KLHK perpotensi memiliki manfaat mempermudah pekerjaan bidang KLHK yang memiliki cakupan wilayah cukup luas. Tipe manfaat yang dimaksud Grindle (1980) adalah jenis manfaat yang diterima oleh target groups dimana seharusnya suatu kebijakan terdapat beberapa jenis manfaat positif bagi pengimplementasi kebijakan.

Penggunaan drone di KLHK sangat dirasakan manfaatnya bagi Direktorat Jenderal (Ditjen) Planologi Kehutanan dan Tata Lingkungan (PKTL) beserta Satker di bawahnya yakni Balai Pemantapan Kawasan Hutan (BPKH). Pada lingkup ini drone bermanfaat untuk mempercepat orientasi wilayah saat tata batas kawasan hutan dilaksanakan. Kegiatan inventarisasi sumber daya hutan sangat terbantu dengan pemotretan menggunakan drone untuk mendapatkan citra resolusi tinggi tanpa gangguan awan pada daerah yang diperlukan.

Ditjen Penegakan Hukum Kehutanan dan Lingkungan (Gakkum) sangat terbantu kegiatan pembuktian kasus di lapangan ketika memerlukan pengecekan lapangan pada wilayah yang sulit dijangkau dengan perjalanan darat. Selain wilayah yang sulit dijangkau karena topografi berat adalah wilayah yang berpotensi terjadi pelanggaran pidana baik menyangkut masalah lingkungan hidup maupun kehutanan. Permasalahan di sini adalah ketika pengelola yang diduga melakukan pelanggaran tidak memberikan izin penerbangan drone. Sementara prosedur pengajuan izin haruslah seizin pengelola 
wilayah yang akan dilakukan operasi penerbangan drone.

Ditjen Konservasi Sumber Daya Alam dan Ekosistem (KSDAE) sangat terbantu pekerjaannya dalam hal memantau wilayah konservasi yang umumnya luas dan memiliki medan dengan topografi berat. Pemantauan satwa yang sensitif terhadap pergerakan manusia dapat dilakukan menggunakan drone. Pembuatan dokumen foto dan video untuk promosi konservasi menjadi pekerjaan dominan yang sangat terbantu dengan kehadiran drone. Hal yang sama dirasakan manfaat drone oleh satker Taman Nasional dan Balai Konservasi Sumber Daya Alam. Masalah yang ada adalah belum cukup landasan kuat untuk menolak permohonan izin penerbangan drone oleh pihak ketiga yang akan beroperasi di kawasan konservasi.

Pusat Diklat SDM dan Balai Diklat serta Sekolah Menengah Kehutanan (SMK) berkepentingan untuk melatihkan kompetensi penggunaan drone tersebut kepada aparatur KLHK dan siswa SMK yang dididik dan dilatihnya. Demikian juga beberapa satuan kerja lain di KLHK merasakan manfaat berupa kemudahan dari pengoperasian drone. Kebijakan yang terkait dengan penggunaan drone tentu berakibat terhadap praktik penggunaan drone pada lingkup satker KLHK ini.

Ditjen Pengelolaan Daerah Aliran Sungai dan Rehabilitasi Hutan (PDAS RH) bersama Balai Pengelolaan Daerah Aliran Sungai dan Hutan Lindung (BPDASHL) sering memanfaatkan drone untuk memotret tanaman hasil rehabilitasi hutan dan lahan (RHL) baik untuk keperluan dokumentasi video, publikasi pada sosial media maupun untuk pemetaan evaluasi tanaman. Selain itu drone juga digunakan mendapatkan citra foto untuk melihat tutupan lahan guna analisa kekritisan lahan.

Direktorat Jenderal Pengelolaan Hutan Lestari memanfaatkan drone umumnya untuk kegiatan monitoring dan evaluasi terhadap pembukaan lahan atau penebangan guna menghitung Penerimaan Negara Bukan Pajak (PNBP) atas bukaan tersebut. Selain itu pemantau areal rehabilitasi dan reklamasi kawasan hutan setelah kegiatan pemanfaatan dan penggunaan kawasan hutan merupakan kegiatan yang terbantu dengan adanya teknologi drone.

Direktorat Jenderal Pengendalian Pencemaran dan Kerusakan Lingkungan memerlukan teknologi drone untuk memvalidasi data laporan perusahaan terkait luas areal terdampak (menghitung luas dampak pencemaran). Permasalahan yang timbul terkait penggunaan drone adalah pihak perusahaan tidak mengizinkan petugas mengoperasikan drone untuk monitoring tersebut. Hal ini menjadi masalah juga ketika pengoperasian drone harus mendapatkan rekomendasi dari pengelola wilayah perusahaan yang bersangkutan. Sehingga kontra produktif dengan tugas validasi tersebut.

Direktorat Jenderal Pengelolaan Sampah, Limbah, dan Bahan Berbahaya dan Beracun (Ditjen PSLB3) memanfaatkan drone untuk kegiatan monitoring dan evaluasi pembuangan tailing dan limbah B3 yang dilakukan pelaku usaha.

Masalah yang umum dirasakan Satker KLHK adalah belum difahaminya klasifikasi ruang udara, peraturan, dan prosedur perizinan penggunaan drone. Prosedur perizinan yang memerlukan rekomendasi pengelola wilayah pada kegiatan monitoring dan evaluasi dan validasi sering terhambat dengan tidak diizinkannya pengoperasian drone oleh pengelola. Belum diaturnya penggunaan drone milik instansi pemerintah yang termasuk kategori pesawat negara menjadi penghambat belum didaftarkannya drone milik Satker KLHK.

\section{B. Menganalisis Isi Kebijakan Pendukungnya}

\section{Isi Kebijakan (Content of Policy)}

Faktor isi kebijakan (content of policy) meliputi 6 (enam) indikator yakni: a) 
kepentingan kelompok sasaran, b) tipe manfaat, c) derajat perubahan yang diinginkan, d) letak pengambilan keputusan, e) pelaksana program, dan f) sumber daya yang dilibatkan.

\section{a. Kepentingan KLHK}

Kepentingan kelompok yang dipengaruhi oleh kebijakan, menurut Marilee S. Grindle (1980), menyangkut sejauh mana kepentingan kelompok sasaran atau target groups termuat dalam isi kebijakan. Kepentingan KLHK, dalam visinya adalah "Keberlanjutan Sumber Daya Hutan dan Lingkungan Hidup" (KLHK, 2020). Keberlanjutan tersebut haruslah memenuhi prinsip-prinsip pengelolaan hutan lestari yakni kelestarian ekonomi, ekologi, dan sosial (Purbawiyatna et al., 2011).

Kebijakan-kebijakan utama yang dicermati terkait penggunaan drone ini adalah PM.37/2020 dan PermenLHK No.P.16/ MenLHK/Setjen/KKL.1/2018 (P.16/2018) tentang Pengoperasian PUTA Lingkup KLHK. Pada saat penelitian, PM.37/2020 dan P.16/2018 adalah peraturan terbaru terkait PUTA meskipun penyesuaian P.16/2018 terhadap terbitnya PM.37/2020 belum dilakukan. Peraturan Pemerintah Nomor 12 Tahun 2014 (PP12/2014) tentang Tarif Penerimaan Negara Bukan Pajak (PNBP) turut dicermati karena berhubungan erat dengan penggunaan drone di kawasan hutan ini. Ketiga peraturan inilah yang paling relevan ditelaah isinya ketika mengukur dampak terhadap kelestarian hutan dan lingkungan sebagai kepentingan Kementerian LHK.

Hasil kajian ketiga peraturan menunjukkan bahwa belum seluruh isinya memenuhi kriteria dan indikator kelestarian ekosistem hutan baik kriteria ekologis/lingkungan, kriteria sosial, dan kriteria ekonomi. Meskipun demikian ketiga peraturan ini sebenarnya sudah cukup baik dan dapat saling melengkapi.

\section{b. Tipe Manfaat Bagi KLHK}

Hasil penelitian ini mencatat bahwa kebijakan penggunaan PUTA pada KLHK dirasakan terdapat manfaat positif meski ada sisi negatifnya. Manfaat positif dari adanya pengaturan pengoperasian PUTA melalui PM.180/2015 dan PM.37/2020 adalah dapat meningkatkan keselamatan penerbangan, meningkatkan kinerja PUTA, dan dapat mengendalikan operasi PUTA di lingkungan KLHK (KLHK, 2018). Hal positif lain dengan adanya pengaturan ini adalah otoritas pengelola kawasan hutan dilindungi karena dapat menolak usulan penerbangan pihak lain bila mengganggu wilayah yang dikelolanya sebagaimana PM.37/2020 butir 4.5 huruf (j).

Manfaat negatifnya adalah pembatasan dan kewajiban perizinan penerbang PUTA meskipun itu di wilayah kerja kawasan hutan sendiri. Ketentuan bahwa semua kegiatan untuk survey udara, pemetaan dan/atau foto udara pada wilayah tertentu harus memiliki Security Clearance (butir 4.13) juga merupakan manfaat yang tidak menguntungkan bagi KLHK.

c. Derajat Perubahan yang Terjadi di KLHK

Derajat kebijakan yang ingin dicapai haruslah memiliki skala yang jelas (Grindle, 1980). Ada tiga perubahan penting dari kebijakan pengoperasian PUTA PM.37/2020, yakni: perizinan terbang, pendaftaran pesawat, serta kompetensi dan sertifikasi pilot drone.

\section{1) Perizinan terbang}

Terbitnya PM.37/2020 berimplikasi kepada proses layanan perizinan yang harus diberikan oleh Kementerian Perhubungan. Pada lingkup KLHK hal itu dinyatakan dalam P.16/2018 yang mana perlu disesuaikan terhadap PM.37/2020.

Hingga penelitian dilakukan, sebagian besar pengoperasian drone di KLHK belum memproses perizinan. Belum diprosesnya perizinan ini berdasarkan argumen bahwa: a) PUTA yang dimiliki oleh Kementerian LHK beserta Satker di bawahnya termasuk kategori pesawat udara negara, yang pengaturannya belum diterbitkan; b) ketinggian terbang di bawah ketinggian $120 \mathrm{~m}$; c) sudah izin ke Satker Pengelola Kawasan Hutan; d) lokasi terbangnya jauh melebihi $500 \mathrm{~m}$ dari batas pemukiman; e) tidak mengetahui bahwa di 
kawasan hutan juga termasuk wilayah yang dikontrol oleh otoritas bandara.

Terkait ketidaktahuan berarti komunikasi tentang wilayah mana saja yang termasuk areal terkontrol dan tidak terkontrol sebagaimana diatur dalam peraturan PM.37/2020 belum sampai semua ke tingkat pengguna. Hambatan komunikasi inilah yang menurut (Edward III, 1984) menjadi penghambat implementasi kebijakan di lapangan.

\section{2) Pendaftaran pesawat}

Perubahan yang diinginkan dengan keluarnya PM.37/2020 diantaranya adalah perlunya pendaftaran pesawat drone ke Kementerian Perhubungan. Hal ini menjadi suatu syarat dalam pemberian persetujuan pengoperasian PUTA.

Pada Kementerian Lingkungan Hidup dan Kehutanan, PUTA telah didaftar oleh Pustek selaku Koordinator Pengendali Operasi di KLHK. Dari 265 Satker pada lingkup KemenLHK, sebanyak 152 (57\%) Satker/ UPT telah memiliki PUTA, 29 (11\%) Satker/ UPT belum memiliki, dan 84 (32\%) Satker/ UPT belum terdata (Gambar 2).

Sampai dengan penelitian ini dilakukan, PUTA milik KLHK belum didaftarkan ke Kemenhub. Hal ini dilakukan dengan alasan: pertama, peraturan mengenai pesawat milik negara belum ada. Kedua, pada aplikasi SIDOPI (Sistem Registrasi Drone dan Pilot Drone Indonesia) kanal untuk drone milik instansi pemerintah belum ada alternatif pilihannya.

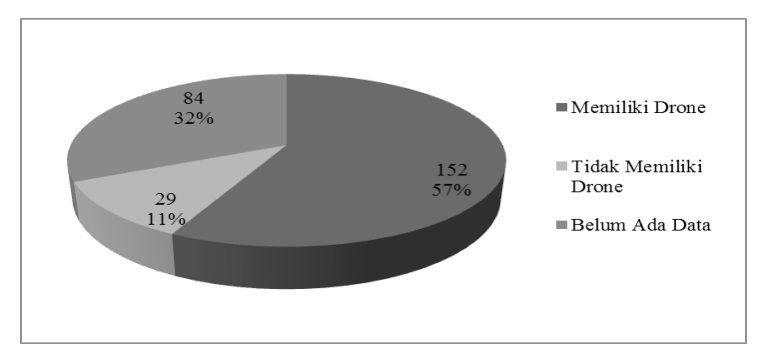

Sumber (Source): (Pustek, 2020)

Gambar 2. Data Kepemilikan PUTA pada Satker/UPT Kementerian LHK

Figure 2. Data on Drone Ownership at the Satker/ UPT of the Ministry of Environment and Forestry
3) Kompetensi dan sertifikasi pilot drone

PM.37/2020 dan P.16/2018 mewajibkan pengguna PUTA memiliki kemampuan yang cukup sejak persiapan hingga pendaratan (P.16/2018 pasal 3 (4)). Sertifikat pilot PUTA dimaksud adalah bukti kompetensi pilot. Bukti ini dapat berupa sertifikat pelatihan maupun sertifikat kompetensi. Karena jika merujuk pada Civil Aviation Safety Regulations (CASR) 107.13 dan 107.65 sertifikat operator tersebut adalah lulus tes pengetahuan tentang aeronautical.

\section{Kompetensi dan Sertifikasi Aparatur di Kementerian LHK}

Dampak peraturan P.16/2018 dan PM.37/2020 adalah adanya perubahan perilaku organisasi dan aparatur KLHK dalam upaya memenuhi kompetensi operator PUTA. Hingga penelitian ini dilakukan, terdapat 363 personil PUTA yang di tetapkan dengan surat keputusan. Dari jumlah tersebut sebanyak 268 personil telah mengikuti pelatihan dan 95 orang belum mengikuti baik pelatihan maupun bimbingan teknis. Sebanyak 98 personil diantaranya telah diberikan peningkatan kompetensi melalui bimbingan teknis (bimtek) yang dilaksanakan oleh Pustek (Gambar 3).

Selain peningkatan kompetensi yang dilakukan melalui Bimtek oleh Pustek dan penyelenggara lain, telah dilatih 75 personil PUTA oleh Pusdiklat SDM LHK (Silvika, 2020). Belum diperoleh informasi apakah

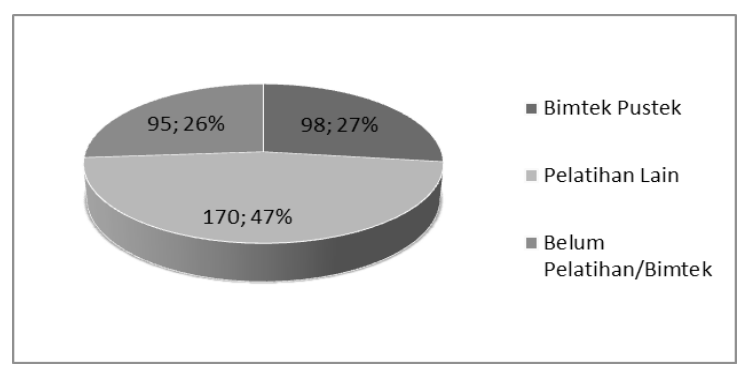

Sumber (Source): (Pustek, 2020)

Gambar 3. Personil PUTA KLHK dan Peningkatan Kompetensinya

Figure 3. MoEF Drone Personnel and Competency Improvement 
75 personil ini termasuk dalam 363 personil yang disebutkan terdahulu.

Dengan asumsi bahwa 75 ini bukan termasuk personil yang telah ditetapkan sebagai operator PUTA, maka jumlah operator PUTA di KLHK telah ada 438 orang dengan 343 telah ditingkatkan kompetensinya baik melalui bimbingan teknis, pelatihan di Pusdiklat SDM LHK maupun pelatihan lainnya.

\section{Pilot PUTA bersertifikat}

Sertifikat pilot PUTA di sini dapat dimaknai menjadi dua yakni sertifikat peningkatan kompetensi dan sertifikat kompetensi (lisensi pilot). Jika merujuk sertifikat pilot adalah lisensi seorang pilot, maka dari 438 personil PUTA pada Kementerian LHK baru terdata 1 orang pilot PUTA berlisensi (Pustek, 2020).

Dari perubahan yang diinginkan dalam PM.37/2020 tentang perizinan, pendaftaran pesawat, dan sertifikasi pilot drone dapat dicatat beberapa hal sebagai berikut. Pertama, belum melakukan perizinan karena beranggapan pekerjaan KLHK melakukan penerbangan pada wilayah sendiri. Kedua, pendaftaran pesawat belum dilakukan karena status pesawat drone milik KLHK adalah kategori pesawat negara, dan hingga saat ini ketentuan drone sebagai pesawat negara tersebut belum ada. Ketiga, sertifikasi pilot drone belum dilakukan karena saat penelitian belum tersedia mekanisme sertifikasi dimaksud. Yang telah ada adalah sertifikasi yang dilakukan FASI dimana itu menyangkut pilot drone untuk kegiatan rekreasi dan hobi. Sementara pekerjaan dinas di KLHK bukan termasuk rekreasi dan hobi. Keempat, meskipun demikian perubahan sebagai upaya meningkatkan kompetensi telah banyak dilakukan, dengan sebagian kecil operator telah memiliki sertifikat menerbangkan PUTA.

\section{d. Letak Pengambilan Keputusan di KLHK}

Berkaitan dengan keputusan memberikan izin dan menolak permohonan pihak ketiga yang akan menerbangkan PUTA di kawasan hutan, pimpinan Satker KLHK menyatakan perlu kejelasan prosedur operasi yang standar (SOP) dari tingkat KLHK untuk dapat dipedomani aparatur di lapangan.

Pustek mendata seluruh PUTA yang dimiliki Satker di KLHK. Kepala Satker berkewajiban melaporkan kepemilikan dan kegiatan pengoperasian PUTA di Satkernya. Namun Pustek, selaku Koordinator Pengendali PUTA KLHK, tidak mendaftarkan PUTA tersebut ke Kemenhub dan berharap pendaftaran sebaiknya dilakukan Satker.

Jadi pengambilan keputusan dalam pengoperasian PUTA di KLHK berada pada Satker masing-masing yang perlu pedoman dari Pusat. Pustek hanya mendata dan menerima laporan hasil operasi PUTA. Namun demikian Pustek tengah menyiapkan pedoman sebagaimana diharapkan oleh Satker. Struktur birokrasi yang bertingkat seperti ini, menurut Erward III (1984), memengaruhi tingkat implementasi kebijakan penggunaan drone.

PM.37/2020 maupun peraturan sebelumnya, menyasar kepada perorangan sebagai pilot yang memiliki drone atau perusahaan. Sehingga keputusan berada pada perseorangan atau pimpinan perusahaan. Secara spesifik pengambilan keputusan yang perlu dilakukan pimpinan instansi pemerintah belum ada. Saat ini yang dilakukan KLHK adalah menunggu dan/atau mengikuti ketentuan sebagaimana prosedur pengoperasian PUTA milik perusahaan.

Letak pengambilan sebuah keputusan di dalam sebuah kebijakan memegang peranan penting dalam pelaksanaan sebuah kebijakan. Apakah letak sebuah program sudah tepat atau belum. Oleh karena itu pada bagian ini harus dijelaskan dimana letak pengambilan keputusan dari suatu kebijakan yang akan diimplementasikan (Grindle, 1980). Keputusan disini termasuk keputusan terkait alokasi pendanaan. 


\section{e. Pelaksana Kebijakan Drone di KLHK}

Pelaksana program sangat penting dalam mendukung implementasi kebijakan. Oleh karena itu perlu disebut dengan rinci dan pelaksana tersebut memiliki kompetensi serta kapabilitas yang cukup (Trisnanti, 2014). Pustek KLHK memiliki peran sebagai Koordinator Pengendali Operasi PUTA pada lingkup KLHK. Pendataan PUTA dan operator yang tersebar pada Satker KLHK dilakukan oleh Pustek. Hal ini disebutkan juga pada P16 tahun 2018. Kegiatan sosialisasi, bimbingan teknis kepada operator PUTA pada Satker lingkup KLHK telah dilakukan sebanyak 3 (tiga) kali yakni dua kali pada tahun 2018 dan sekali pada 2020.

Pusat Diklat SDM LHK berperan sebagai pelaksana kebijakan penggunaan PUTA ini dengan menyusun kurikulum pelatihan dan melaksanakan pelatihan bagi aparatur KLHK pada tahun 2020. Direktorat IPSDH tercatat turut aktif melaksanakan kebijakan ini dengan melakukan beberapa kali pelatihan untuk keperluan inventarisasi. Selain IPSDH, Sekretariat Jenderal Perhutanan Sosial dan Kemitraan Lingkungan (PSKL) KLHK juga pernah melaksanakan pelatihan. Tidak ketinggalan Balai Pengelolaan Hutan Produksi (BPHP) melaksanakan penyebarluasan pengoperasian PUTA ini melalui inhouse training (Pustek, 2020).

Pustek KLHK memiliki kapasitas dalam melaksanakan bimbingan teknis yang didukung pendanaan yang dialokasikannya. Sumber daya untuk melibatkan pihak lain dalam kegiatan bimbingan teknis juga dimiliki Pustek. Pusat Diklat SDM LHK sebagai pelaksana pengembangan kompetensi SDM memiliki sumber daya otoritas dalam penyusunan kurikulum pelatihan dan pelaksanaan pelatihan. Tenaga widyaiswara/ pelatih KLHK yang kompeten dalam penggunaan drone tercatat sebanyak 15 orang baik berkedudukan di pusat maupun di daerah.

f. Sumber Daya yang Dilibatkan di KLHK

Kecukupan sumber daya menjadi penting dalam implementasi suatu kebijakan (Trinanti, 2014). Kecukupannya bisa mendukung suksesnya program, demikian sebaliknya jika kurang akan dapat menghambat (Erward III, 1984).

Dari sisi peralatan, 57\% Satker KLHK telah memiliki drone dengan total sebanyak 427 unit drone yang tersebar pada Satker/ UPT. Sumber daya operator yang dimiliki KLHK sebanyak 438 personil dengan sebagian besar telah mengikuti pelatihan meski baru sebagian kecil memiliki sertifikat pilot drone (Pustek. 2020).

Selain sumber daya internal, APDI dan FASI, adalah sumber daya eksternal yang dilibatkan dalam kegiatan bimbingan teknis yang dilaksanakan Pustek. Selain potensi internal Pusat Diklat SDM LHK yang berkompeten dalam penggunaan drone, Pusat Diklat juga melibatkan praktisi dari luar seperti TNI AU, Institut Teknologi Bandung, Universitas Papua, dalam pelaksanaan Saresehan Webinar Drone. GIZ Forclimesuatu lembaga kerja sama IndonesiaJerman merupakan sumber daya lain yang dilibatkan dalam mendukumg pelaksanaan pengembangan kompetensi PUTA di Pusat Diklat SDM LHK.

Dari penelitian ini tercatat bahwa beberapa Satker telah melaksanakan pengembangan kompetensi dengan melibatkan baik potensi internal maupun eksternal dengan beberapa keterbatasannya. Keterbatasan dan masih belum terkoordinasikannya pengunaan sumber daya inilah yang menurut Erward III (1984) dapat menjadi penghambat implementasi suatu kebijakan.

\section{Lingkungan Implementasi (Context of Implementation)}

Faktor lingkungan implementasi (context of implementation) terdiri 3 (tiga) indikator yakni: a) kekuasaan, kepentingan, dan strategi aktor yang terlibat, b) karakteristik lembaga dan penguasa, serta c) kepatuhan dan daya tanggap. 
a. Kekuasaan, Kepentingan, dan Strategi yang Diterapkan

Pemetaan stakeholder dilakukan dengan menginterpretasikan kepentingan dan perannya dalam implementasi kebijakan penggunaan drone. Terdapat stakeholder internal dan eksternal dalam implementasi kebijakan PUTA di KLHK (Gambar 4).

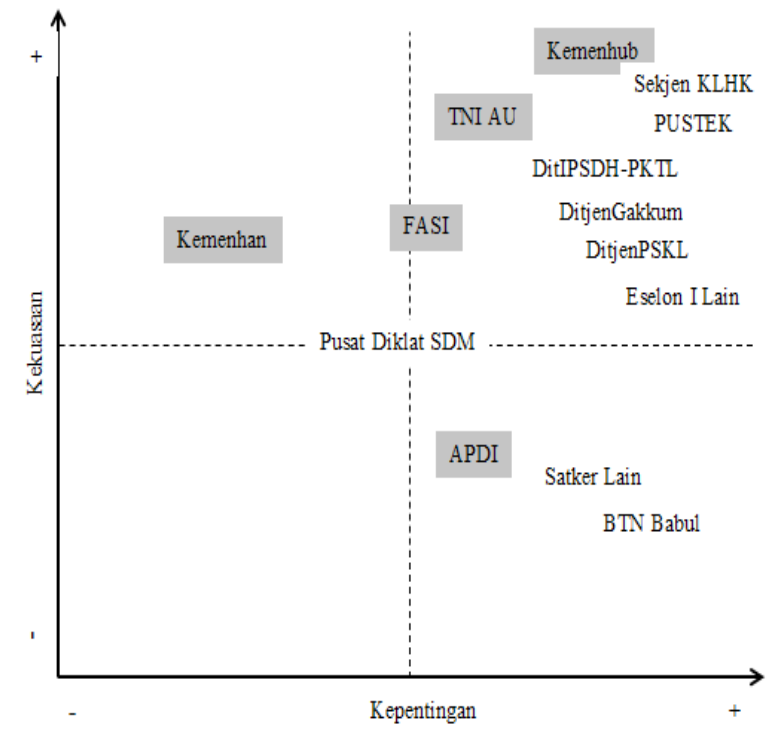

Keterangan : $=$ Eksternal $\quad \square=$ Internal

Gambar 4. Kekuasaan dan Kepentingan Aktor Figure 4. Powers and Interests of Actor

Pustek sebagai representasi Sekretariat Jenderal KLHK memiliki kekuatan sebagai koordinator. Kepentingannya adalah tertib dan selamatnya penggunaan PUTA di KLHK. Sekretaris Jenderal (Sekjen) KLHK, Sekretaris Direktorat Jenderal (Sekditjen) Teknis, Sekretaris tiap-tiap eselon I, pimpinan Satker di daerah merupakan stakeholder internal. Biro Hukum KLHK, Pusat Diklat SDM LHK adalah juga merupakan stakeholder internal KLHK yang kekuatannya secara fisik dapat melaksanakan operasi PUTA kapan saja, namun secara administratif memerlukan ketentuan. Kepentingannya adalah terlaksana pekerjaan sesuai tugas dan kewenangannya.

Sementara Kementerian Perhubungan, Kementerian Pertahanan, TNI AU memiliki kekuatan dalam pengaturan ruang udara di Indonesia. Kepentingannya adalah keselamatan penerbangan di Indonesia. FASI,
APDI, serta penyedia jasa pelatihan lain adalah merupakan stakeholder eksternal yang banyak bergerak melaksanakan pelatihan terkait penggunaan drone dengan informasi terbaru.

Maka strategi Pustek adalah melibatkan berbagai kekuatan internal dan eksternal yang ada untuk menyusun pedoman teknis penggunaan PUTA di KLHK. Biro Hukum KLHK adalah pihak penting yang dilibatkan dalam penyusunan Pedoman Teknis Pengoperasian PUTA KLHK tersebut.

Satker KLHK umumnya memiliki kepentingan besar namun kekuasaannya memerlukan payung hukum yang dapat memayungi operasi dan perizinan PUTA di wilayahnya. Maka strateginya adalah menunggu arahan teknis, menunggu adanya pedoman atau petunjuk teknis dari atasannya.

Satker pengelola kawasan hutan, seperti TN Babul, memiliki kekuasaan besar terhadap perizinan operasi PUTA oleh pihak ketiga di wilayah kerjanya. Satker bisa merekomandasikan atau tidak merekomendasikan pihak ketiga yang mengajukan permohonan penerbangan di wilayahnya. Hal tersebut sejalan dengan pendapat (Sankey et al., 2019) bahwa land manager dapat mengidentifikasi dan memonitor secara terus menerus kesehatan lahan sesuai dengan kebijakan lahan dan strategi manajemen. Dasar pertimbangan untuk merekomendasikan atau tidak adalah zonasi wilayah yang dikelolanya. Zonasi wilayah kerja menjadi dasar pertimbangan dalam perizinan operasi PUTA ini.

Pusat Diklat SDM LHK memiliki kepentingan untuk memberikan pelayanan pengembangan kompetensi kepada aparatur KLHK termasuk dalam pengetahuan, keterampilan dan sikap yang menyangkut keselamatan penerbangan, dan pengoperasian PUTA. Kepentingan ini termasuk sedang mengingat banyak jenis pelatihan yang harus dilayani. Kekuasaan Pusat Diklat SDM LHK adalah kewenangannya mendesain materi-materi yang termuat dalam kebijakan 
pengoperasian PUTA ke dalam kurikulum pelatihan. Kekuatan ini termasuk besar karena dapat mewarnai kompetensi ASN yang ditugaskan menjadi pilot drone di KLHK.

Penelusuran dokumen kurikulum di Pusat Diklat SDM LHK telah disusun Kurikulum Pelatihan Drone untuk Pemetaan bernomor SK.362/Dik/PEPE/Dik-2/9/2019. Keterbatasan dari kurikulum ini adalah belum memuat materi aeronautical knowlegde yang menjadi persyaratan sertifikasi pilot drone. oleh karena itu Pusat Diklat SDM LHK akan mengatur strategi dengan menyusun kurikulum pelatihan PUTA yang memuat materi tersebut dan lulusan pelatihan dapat memperoleh sertifikat pilot drone.

\section{b. Karakteristik Lembaga}

Menurut Grindle (1980), keberadaan institusi dan rezim yang sedang berkuasa mempengaruhi keberhasilan implementasi kebijakan. Menurut PemenLHK Nomor P.18/ MENLHK-II/2015 tentang Organisasi dan Tata Kerja Kementerian Lingkungan Hidup dan Kehutanan, Kementerian LHK adalah suatu kementerian yang memiliki 18 organisasi setingkat eselon I. Ada 1 (satu) sekretariat dan inspektorat jenderal, 9 (sembilan) organisasi teknis berupa direktorat jenderal, 2 (dua) organisasi berupa badan, dan 5 (lima) staf ahli menteri. Kementerian ini bertugas mengelola areal, yang dialoksasikan sebagai kawasan hutan, seluas 120,6 juta hektar. Luas ini setara dengan sekitar 63 persen dari luas daratan di Indonesia (KLHK, 2018b).

Dengan karakteristik organisasi yang besar dengan cakupan wilayah kerja yang sangat luas menjadi kendala tersendiri terhadap implementasi kebijakan penggunaan drone. Banyak kawasan hutan yang jauh jangkauan komunikasi dan komunitas serta jalur penggunaan ruang udara. Karakteristik wilayah TN Babul dapat menjadi salah satu gambaran wilayah Satker di daerah yang cukup luas dengan topografi yang berat.

\section{c. Tingkat Kepatuhan dan Daya Tanggap Terhadap Kebijakan Drone di KLHK}

Tingkat kepatuhan dan daya tanggap KLHK terhadap kebijakan penggunaan drone ini ditinjau dari 9 (sembilan) aktivitas tindak lanjut menyikapi kebijakan tersebut. Kegitan tersebut adalah: penerbitan peraturan menteri, penyusunan pedoman teknis, pendataan PUTA dan pilotnya, pembuatan petunjuk teknis, pengaturan penggunaan drone di UPT, peningkatan kompetensi, penyertifikatan pilot PUTA, perizinan PUTA, dan penyediaan asuransi kerugian.

\section{1) Penerbitan P.16 Tahun 2018}

KLHK telah merespon terbitnya Permenhub PM.180/2015 yang diperbaharui dengan PM.47/2016 dengan mengeluarkan Permen LHK P.16/2018. Namun dengan dikeluarkannya PM.37/2020, yang mengganti PM.180/2015, maka P.16/2018 menjadi tidak relevan lagi.

2) Penyusunan Pedoman Teknis

Pengoperasian PUTA Lingkup KLHK

Untuk mengantisipasi tidak relevannya P.16/2018 maka Pustek telah berinisiatif menyusun Pedoman Teknis Pengoperasian PUTA lingkup KLHK. Pedoman yang sudah pada tahap finalisasi ini akan disebarkan ke seluruh Satker KLHK dalam bentuk buku agar dapat menjadi rujukan.

\section{3) Pendataan PUTA dan Pilot PUTA}

Pendataan PUTA dan operator yang dimiliki oleh seluruh Satker KLHK telah dilakukan oleh Pustek. Meskipun kepatuhan untuk mendaftarkan PUTA ke Kemenhub belum dilakukan oleh Pustek. Hal ini mengingat ketentuan pasal 5 PM.37/2018 yang menyatakan bahwa PUTA milik instansi pemerintah berlaku ketentuan sebagai pesawat milik negara yang akan diatur tersendiri. Sementara peraturan penjelas terkait pesawat milik negera tersebut belum tersedia. 
4) Pembuatan Petunjuk Teknis Direktorat IPSDH

Direktorat IPSDH telah mengeluarkan SOP Nomor: SOP.1/IPSDH/PSDH/ PLA.1/1/2020 tanggal 24 Januari 2020 tentang Petunjuk Teknis Pengecekan Lapangan Dengan Menggunakan Pesawat Udara Tanpa Awak (PUTA). SOP ini merupakan pedoman teknis bagi staf yang melaksanakan pengecekan lapangan dalam rangka mendukung pemantauan sumber daya hutan lingkup Direktorat IPSDH. Pada SOP ini diberikan petunjuk mengenai: persiapan pengecekan, pelaksanaan pengecekan, dan pasca pengecekan.

5) Pengaturan Penggunaan Drone di Kawasan Taman Nasional Komodo

Terdapat dua aturan penggunaan PUTA di kawasan Balai Taman Nasional Komodo yang terletak di Kabupaten Manggarai Barat, Provinsi Nusa Tenggara Timur. Kedua aturan tersebut berupa surat jawaban dan berupa pengumuman (Pradana, 2019).

Surat Kepala Balai Taman Nasional Komodo Nomor S.4432/BTNK-1/2016 merupakan balasan surat terhadap Deputi Bidang Pengembangan Destinasi dan Industri Pariwisata terkait izin penggunaan drone. Pada surat tersebut memuat aturan tentang penggunaan drone di kawasan Taman Nasional Komodo.

Surat Kepala Balai Taman Nasional Komodo dengan Nomor S.582/T.17/TU/ HMS/ 04/2018 merupakan Pengumuman Balai Taman Nasional Komodo. Dalam pengumuman pada angka 8 (delapan) dinyatakan bahwa penggunaan drone di dalam kawasan Taman Nasional Komodo harus mendapatkan izin dari Taman Nasional Komodo dan harus sesuai dengan persyaratan yang dikeluarkan oleh Kemenhub RI. Sama seperti aturan yang dibuat sebelumnya, penggunaan dasar hukum masih menggunakan aturan terdahulu yang belum diubah. Akan tetapi, dalam pengumuman tersebut tidak mencantumkan pembayaran untuk mendapatkan izin penggunaan drone.

6) Peningkatan Kompetensi Operator PUTA

Berbagai upaya dilakukan para pihak dalam peningkatan kompetensi operator PUTA. Terdapat berbagai kategori upaya peningkatan kompetensi operator PUTA di KLHK yakni melalui bimbingan teknis di Pusat Keteknikan, upaya peningkatan kompetensi yang lain, dan pelatihan yang diselenggarakan oleh Pusdiklat SDM LHK. Berbagai upaya tersebut, bila merujuk pada Peraturan Lembaga Administrasi Negera (Perlan) Nomor 10 Tahun 2018 tentang Pengembangan Kompetensi Pegawai Negeri Sipil, merupakan bagian dari kegiatan pengembangan kompetensi.

7) Kepatuhan Terhadap Sertifikasi Pilot PUTA

Kepatuhan mendaftarkan pilot PUTA pada lingkup KLHK juga masih terbatas. Tercatat dari database Pustek (2020), dan data alumni pelatihan di FASI pada tahun 2020 ada 7 (tujuh) dari 438 orang pilot PUTA KLHK yang telah bersertifikat. Selebihnya belum bersertifikat.

8) Kepatuhan Terhadap Perizinan Penggunaan PUTA

Kepatuhan terhadap perizinan pengoperasian PUTA dilacak dari pengoperasian pada saat pengoperasian oleh pegawai KLHK, serta perizinan pengoperasian PUTA oleh pihak lain.

\section{(a) Perizinan Pengoperasian PUTA oleh Pegawai}

Sebagian kecil namun telah dimulai proses pengajuan izin operasi PUTA dilaksanakan oleh pegawai KLHK. Namun belum mendapatkan izin sebagaimana mestinya. Hal ini disebabkan pertama, waktu pengajuan terlalu dekat, dimana seharusnya paling lambat dua minggu sebelum pelaksanaan. Yang kedua, PUTA yang digunakan untuk praktik belum teregistrasi di Kemenhub. 
Sebagian besar pengoperasian PUTA belum melalui prosedur perizinan sebagimana mestinya. Hal ini dikarenakan pengoperasian drone lebih banyak untuk pengambilan foto dan video dokumentasi dengan ketinggian di bawah $100 \mathrm{~m}$ dari permukaan tanah. Selain itu penggunaan PUTA ini adalah pada wilayah kerja sendiri. Namun koordinasi dengan pemerintah setempat maupun pengelola wilayah telah dilakukan. Argumen lain belum memproses perizinan adalah karena belum adanya petunjuk teknis atau SOP yang harus dipedomani dalam pengoperasian PUTA di lingkungan KLHK.

(b) Perizinan Pengoperasian PUTA Pihak Lain

Pengunjung umum selama ini belumbanyak yang melakukan aktivitas penerbangan drone di kawasan konservasi. Seperti yang terjadi di kawasan wisata Bantimurung, terdapat penerbangan untuk mengambil foto-foto di bagian depan kawasan, tetapi tidak masuk ke dalam kawasan konservasi.

Pengelola TN Babul merasa belum mengetahui adanya landasan kuat untuk mengizinkan atau melarang jika ada pengunjung akan mengoperasikan PUTA di wilayah TN Babul. Padahal pada P.16/2018 disebutkan bahwa pengoperasian PUTA pada kawasan hutan oleh pihak ketiga wajib mendapatkan persetujuan dari Satker pengelola wilayah yang bersangkutan dan harus didampingi oleh personil dari Satker terkait, serta wajib melaporkan hasil pengoperasian PUTA kepada Satker yang bersangkutan.

Gambaran di TN Babul tersebut menunjukkan bahwa meskipun ada P.16/2018 yang dapat menjadi landasan untuk pendampingan operasi PUTA di wilayah kerjanya, namun pengelola wilayah merasa belum mengetahui dan masih perlu payung hukumnya. Oleh karena itu implementasi kebijakan PUTA penting diimplementasikan di KLHK baik level pusat maupun sampai ke level Satker. Perlunya segera mengimplementasikan peraturan ini sejalan dengan (Syahbani, 2020).
9) Kepatuhan Menyediakan Asuransi Kerugian Pihak Ketiga

Kewajiban menjamin kerugian akibat kegagalan pengoperasian PUTA sebagaimana amanat PM.37/2020 dan P.16/2018 belum dilaksanakan oleh personil PUTA di lokasi studi. Hal ini tersirat dari informasi beberapa informan bahwa: a) perizinan terbang bagi operator di TN Babul juga belum dilakukan, dengan sendirinya kewajiban asuransi sebagai syarat dipastikan belum dibuat; b) perizinan terbang, baik izin dari Kemenhub atau dari bandara terdekat, bagi pengunjung juga belum diperiksa; c) Informasi terkait P.16/2018 yang mengharuskan pendaftaran PUTA dan sertifikasi pilot PUTA belum sampai ke lokasi, apalagi terkait PM.37 tahun 2020 yang mewajibkan asuransi dan perizinan terbang.

Pengoperasian PUTA pada lokasi wisata seperti di Bantimurung sangatlah berbahaya bagi komunitas pengunjung di bawahnya. Catatan kegagalan terbang yang beberapa kali terjadi di lokasi studi selama ini hanya berakibat hilang atau rusaknya perangkat PUTA. Namun akan fatal akibatnya jika kegagalan terbang tersebut menimpa kendaraan, pengunjung, dan fasilitas milik orang lain di bawahnya. Oleh karena itu penjaminan kerugian pihak ketiga oleh orang yang mengoperasikan PUTA mutlak perlu diperhatikan sebagaimana diamanatkan pada P.16/2018 dan PM.37/2020. Potensi kecelakaan ini sesuai dengan catatan (Kardasz et al., 2016) akan pentingnya menjaga keselamatan sipil.

\section{Penyempurnaan Implementasi Penggunaan Drone yang Aman dan Efektif}

Hasil kajian ketiga peraturan menunjukkan bahwa belum seluruh isinya memenuhi kriteria dan indikator kelestarian ekosistem hutan baik kriteria ekologis/lingkungan, kriteria sosial, dan kriteria ekonomi (Tabel 1). Oleh karena itu penyempurnaan terhadap isi maupun implementasi kebijakan itu sendiri penting demi mewujudkan penggunaan drone di KLHK yang aman. 
Tabel 1. Kriteria dan Indikator Kelestarian Ekosistem Hutan pada Peraturan Penggunaan Drone Table 1. Criteria and Indicators of Forest Ecosystem Sustainability in the Regulation of the Use of Drones

\begin{tabular}{|c|c|c|c|c|}
\hline $\begin{array}{l}\text { Kriteria } \\
\text { (Criteria) }\end{array}$ & $\begin{array}{c}\text { Indikator kelestarian } \\
\text { (Sustainability Indicators) }\end{array}$ & P.16/2018 & PM.37/ 2020 & PP12/2014 \\
\hline \multirow{4}{*}{$\begin{array}{l}\text { Ekologis/ } \\
\text { Lingkungan } \\
\text { (Ecology) }\end{array}$} & $\begin{array}{l}\text { Pernyataan secara eksplisit atau } \\
\text { implisit dalam peraturan }\end{array}$ & $\sqrt{ }$ (Implist) & $\sqrt{ }$ (Implist) & $\mathrm{x}$ \\
\hline & $\begin{array}{l}\text { Mendukung kehidupan organisme } \\
\text { yang sehat pada ekosistem hutan }\end{array}$ & $\begin{array}{c}\sqrt{ }(\text { Pasal } 2(2 b) \\
\text { Pasal } 3(4), \\
\text { Pasal } 3(5 b) \\
\text { Pasal } 3(5 c)\end{array}$ & $\begin{array}{l}\sqrt{ }(\text { Pasal 2(b) } \\
\text { Butir 3.7, butir } \\
\quad 4.5(\mathrm{j})\end{array}$ & $\mathrm{x}$ \\
\hline & $\begin{array}{l}\text { Mempertahankan produktivitas } \\
\text { ekosistem }\end{array}$ & 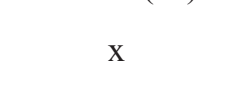 & $\mathrm{x}$ & $\mathrm{x}$ \\
\hline & $\begin{array}{l}\text { Memungkinkan adaptabilitas dan } \\
\text { kemampuan ekosistem untuk pulih } \\
\text { kembali }\end{array}$ & $\mathrm{x}$ & $\mathrm{x}$ & $\mathrm{x}$ \\
\hline \multirow{4}{*}{$\begin{array}{l}\text { Sosial } \\
\text { (Social) }\end{array}$} & $\begin{array}{l}\text { Pernyataan secara eksplisit atau } \\
\text { implisit dalam peraturan }\end{array}$ & $\sqrt{ }$ (Implisit) & $\sqrt{ }($ Eksplisit $)$ & $\mathrm{x}$ \\
\hline & $\begin{array}{l}\text { Mencerminkan keterkaitan dengan } \\
\text { budaya }\end{array}$ & $\sqrt{ }($ Pasal $6(2))$ & $\sqrt{ }($ Butir 4.5 (j) & $\mathrm{x}$ \\
\hline & $\begin{array}{l}\text { Mencerminkan keterkaitan dengan } \\
\text { etika }\end{array}$ & $\sqrt{ }($ Pasal $6(2))$ & $\sqrt{ }($ Butir $4.5(\mathrm{j})$ & $\mathrm{x}$ \\
\hline & $\begin{array}{l}\text { Mencerminkan keterkaitan dengan } \\
\text { norma sosial dan pembangunan }\end{array}$ & $\sqrt{ }($ Pasal $6(2))$ & $\sqrt{ }($ Butir $4.5(\mathrm{j})$ & $\mathrm{x}$ \\
\hline \multirow{3}{*}{$\begin{array}{l}\text { Ekonomi } \\
\text { (Economy) }\end{array}$} & $\begin{array}{l}\text { Pernyataan secara eksplisit atau } \\
\text { implisit dalam peraturan }\end{array}$ & $\mathrm{x}$ & $\mathrm{x}$ & $\sqrt{ }$ (Implisit) \\
\hline & $\begin{array}{l}\text { Menunjukkan manfaat dari hutan } \\
\text { melebihi biaya yang dikeluarkan oleh } \\
\text { unit manajemen }\end{array}$ & $\mathrm{x}$ & $\mathrm{x}$ & $\begin{array}{l}\sqrt{ }[\text { Ketentuan } \\
\text { XVI.D.2.a.3) }\end{array}$ \\
\hline & $\begin{array}{l}\text { Modal yang ekuivalen dapat } \\
\text { diinvestasikan dari satu generasi ke } \\
\text { generasi berikutnya }\end{array}$ & $\mathrm{x}$ & $\mathrm{x}$ & $\mathrm{x}$ \\
\hline
\end{tabular}

Keterangan:

Information:

$\sqrt{ }:$ Diatur dalam regulasi, dan $\mathrm{x}$ : Tidak diatur dalam regulasi

$\sqrt{ }$ : Regulated by regulation, and $x$ : Not regulated by regulation

Sumber/Sources: PP.12 (2014); (KLHK, 2018), Permenhub PM.37 (2020)

\section{1) Menjaga Kelestarian Ekologis/Lingkungan}

Peraturan yang ada telah ditemukan dukungan terhadap kelestarian ekologi/ lingkungan, meski beberapa bagian diperlukan peraturan penjelas guna menjaga lingkungan/ ekologi hutan. Dukungan terhadap kelestarian ekologis/lingkungan tercermin pada P.16/2018 dan PM.37/2020 khususnya indikator mendukung kehidupan organisme yang sehat pada ekosistem hutan (Tabel 1). Meskipun drone digunakan di ruang udara di atas daratan namun penerbangannya berpengaruh terhadap satwa terbang. Suara bising dari drone juga mempengaruhi satwa yang sensitif terhadap benda atau makhluk asing. Penelitian (Hodgson \& Koh, 2016) mencatat bahwa dengan peningkatan penggunaan drone untuk penelitian, perdagangan dan rekreasi, dapat mempengaruhi pola pembibitan dan perilaku hewan. Penggunaan drone untuk penyelamatan satwajugaharus memperhatikan keselamatan dan perkembangan satwa itu sendiri (Nursalikah, 2016). 
Pemenuhan kriteria ini tersirat dalam salah satu tujuan diterbitkannya P.16/2018 yakni meningkatkan keamanan dan keselamatan selama menggunakan dan menerbangkan PUTA sebagaimana tertuang pada (pasal 2 (2b)).

Pada pasal 3 (4), P.16/2018, tersirat pentingnya menjaga keselamatan banyak pihak baik manusia maupun kehidupan ekosistem lainnya akibat penerbangan PUTA. Ketentuan ini mengharuskan pengguna PUTA memiliki kemampuan yang cukup. Dalam pasal 3 (5b) dibenarkan waktu penerbangan PUTA saat siang hari dan terlihat oleh pilot dan/atau pengamat visual. Ketentuan lain menyatakan bahwa PUTA tidak diperbolehkan beroperasi di atas kendaraan atau pesawat terbang yang bergerak kecuali perahu di atas air (pasal 3(5c)).

Ketentuan tersebut adalah dalam rangka menjaga keselamatan baik pengguna maupun pihak lain selain pengguna PUTA. Keselamatan selain pengguna PUTA dapat dimaknai manusia maupun satwa bahkan flora yang mendiami suatu wilayah ekosistem tertentu seperti Taman Nasional.

Penjaminan keselamatan kehidupan baik manusia maupun makhluk lainnya tersirat dalam maksud penerbitan PM.37/2020 (pasal 2 (b)) yakni agar pengoperasian pesawat udara tanpa awak di ruang udara yang di layani di Indonesia lebih tertib, jelas, dan tepat. Ketertiban ini adalah dalam rangka menghindari kecelakaan yang dapat berakibat kerugian baik pada pengguna, pesawat, maupun pihak lain. Menurut penulis, pihak lain tersebut dapat dimaknai manusia dan alam sekitarnya termasuk tumbuhan dan satwa bahkan bangunan atau fasilitas lainnya.

Pada PM.37/2020 terdapat pengendoran atas ketentuan khusus penggunaan pesawat udara tanpa awak dalam PM.180/2015 (butir 3.7). Hilangnya frasa "pengamatan aktivitas hewan dan tumbuhan di taman nasional" pada PM.37 sedikit melemahkan perlindungan terhadap keselamatan ekosistem ketika ditinjau dari kriteria ekologis/lingkungan.
Hingga penelitian ditulis, belum diperoleh jawaban perihal hilangnya frasa ini. Kesan pelemahan tersebut mengingat Taman Nasional dibentuk adalah dalam rangka menyelenggarakan konservasi sumber daya alam dan ekosistemnya di wilayahnya (MenLHK, 2016). Meskipun demikian secara implisit masih tersirat pada PM.37/2020 pada ketentuan 4.5.huruf j terkait perizinan, yakni : untuk kepentingan pemotretan, perfilman atau pemetaan, melampirkan surat dari institusi yang berwenang dan/atau pemilik obyek yang berada di bawah wilayah pengoperasian PUTA (Peraturan Menteri Perhubungan Nomor PM. 37 Tahun 2020. Pengoperasian pesawat udara tanpa awak di ruang udara yang dilayani Indonesia, 2020). Perhatian lebih diperlukan untuk memaknai pernyataan implisit taman nasional sebagai salah satu wilayah yang dinyatakan dalam PM.37/2020 ini.

Cara menjaga ekologi/lingkungan dengan adanya peraturan yang demikian adalah dengan mendetailkan ketentuan 4.5. huruf j dalam PM.37/2020 terkait kewenangan/ atau pemilik obyek di bawah wilayah pengoperasian PUTA. Pendetailan tersebut dapat dituangkan dalam revisi PermenLHK P16/2018. Perlu diamanatkan dalam peraturan turunan tersebut bahwa pihak pengelola kawasan hutan perlu membuat peta zonasi terbang drone sesuai dengan keperluan ekosistem yang dilindunginya.

\section{2) Menghindari Konflik Sosial}

Suatu aktivitas dikatakan lestari secara sosial apabila bersesuaian dengan etika dan norma-norma sosial atau tidak melampaui batas ambang toleransi komunitas setempat terhadap perubahan. Penghormatan terhadap sosial dan budaya secara implisit tersirat pada PM.37/2020 yaitu ketentuan 4 butir 4.5 huruf $\mathrm{j}$ tentang surat dari institusi yang berwenang dan/atau pemilik obyek yang berada di bawah wilayah pengoperasian PUTA. Izin prinsip tersebut dimaknai sebagai penghormatan terhadap aktivitas sosial maupun budaya 
yang ada pada obyek di dataran tersebut. Perlindungan terhadap budaya lokal yang dilakukan pada wilayah tertentu dijamin dengan peraturan menteri ini.

Pada wilayah religi upacara keagamaan di Bali misalnya, tidak diperkenankan adanya perekaman foto maupun video menggunakan drone, apalagi tanpa izin. Perizinan yang diharuskan pada MP.37/2020 adalah bentuk keberpihakan kepada masalah sosial.

Untuk menghindari konflik sosial dalam pengoperasian PUTA oleh aparatur KLHK adalah dengan mengoperasikan PUTA selalu berkomunikasi dan meminta izin kepada pengelola wilayah yang akan dilakukan operasi PUTA. Memang benar jika kawasan hutan negara adalah semua di bawah penguasaan KLHK, akan tetapi kewenangan berada pada Satuan Kerja sebagai pengelola kawasan.

\section{3) Meningkatkan Nilai Ekonomi Hutan}

Dari sisi pendapatan negara, penggunaan PUTA yang memperhatikan aspek ekonomi kawasan hutan diatur secara implisit dalam PP No.12 Tahun 2012 tentang Tarif Penerimaan Negara Bukan Pajak (PNBP). Pada ketentuan XVI.D.2.a.3) terkait Snapshot Film Komersiil disebutkan perangkat yang digunakan adalah

: (1) video kamera, (2) handycam, dan (3) foto. Drone adalah wahana yang membawa kamera yang dapat digunakan untuk fungsi video, maupun foto. Sehingga secara implisit perangkat drone dapat dilakukan pendekatan besaran PNBP baik kategori video kamera, handycam, ataupun foto. Secara eksplisit drone belum ditulis dalam ketentuan PP12/2012 ini.

Untuk meningkatkan nilai ekonomi dari penggunaan PUTA maka upaya menuangkan perangkat PUTA sebagai wahana yang dinyatakan dalam revisi PP.12/2012 perlu dipertimbangkan. Pengelompokan video kamera,handycam, dan fotoperlu ditambahkan lagi PUTA sebagai wahana. Tarif untuk PUTA seharusnya lebih tinggi dari ketiga wahana yang ada karena kemampuan menghasilkan produknya. Saat ini tarif terhadap PUTA baru didekati sama dengan handycam atau video kamera, padahal fungsinya dapat mencakup baik video kamera, handycam, maupun foto. Bila revisi PP.12/2014 yang mengakomodir PUTA ini maka PNBP dari penggunaan PUTA akan lebih tinggi dari yang ada.

Belum diperoleh informasi apakah PNBP yang diperoleh dari penggunaan drone ini digunanakan untuk menjamin kelestarian hutan dan lingkungan atau tidak. Setidaknya dengan melihat pendapatan negara yang telah diatur dengan penggunaan drone ini dapat dilihat potensi sumber-sumber ekonomi yang diperoleh dengan adanya akses drone terhadap kawasan hutan.

Kepentingan KLHK terkait prinsip kelestarian hutan dalam PM.37/2020 dan peraturan lainnya sebagaimana Tabel 1 belum secara implisit maupun eksplisit memuat kriteria kelestarian ekonomi. Meskipun demikian kriteria kelestarian ekologi dapat ditemui secara implisit dan kelestarian sosial dinyatakan secara eksplisit. Pihak KLHK, seperti TN Babul, memiliki misi menjaga kelestarian ekologi. Dengan tidak ternyatakan secara eksplisit dalam peraturan, maka hal ini menimbulkan keraguan dalam mengimplementasikannya di lapangan dalam hal pengoperasian oleh pihak ketiga. Hal tersebut sejalan dengan penjelasan Grindle (1980) bahwa terakomodasinya kepentingan kelompok sasaran akan berpengaruh terhadap kelancaran implementasinya, demikian sebaliknya jika kurang terakomodasi maka pengaruhnya menjadi menghambat implementasi.

\section{4) Menerapkan Teknik Pengoperasian PUTA sesuai SOP}

Untuk dapat mengoperasikan PUTA secara aman, efekif, dan efisien maka seluruh pengguna PUTA di KLHK wajib mengoperasikannya sesuai Standard Operating Procedure (SOP). Mengingat ketentuan dalam PM.37/2020 yang perlu penjelas, dan P.16/2018 sudah kurang relevan 
pada beberapa bagian, maka perlu dibuat suatu peraturan penjelas atau SOP lingkup KLHK yang dapat dipedomani oleh aparatur KLHK.

Pengoperasian PUTA perlu sesuai prosedur yang ada. Prosedur perizinan perlu ditempuh. Prosedur permintaan rekomendasi dari pengelola wilayah jika diperlukan juga perlu dilakukan. Lain halnya pada areal yang berpotensi adanya tindakan pelanggaran hukum, maka Satuan Kerja KLHK perlu berkoordinasi dan membangun kerja sama dengan instansi penegak hukum.

Belum teregistrasinya PUTA dan pilot milik KLHK perlu segera diantisipasi. Jika PUTA dan pilotnya belum teregistrasi maka berpotensi tidak mendapat izin operasi dari pihak berwenang. Jika pengoperasian PUTA di KLHK tidak mengikuti prosedur yang sah maka validitas data menjadi diragukan dan hal ini kontraproduktif dengan pekerjaan KLHK.

Upaya-upaya untuk meningkatkan kompetensi telah banyak dilakukan oleh beberapa pihak dengan berbagai bentuk dan melibatkan sumber daya internal maupun eksternal KLHK, namun masih terfokus pada pilot drone sementara pengambilan keputusan di lapangan berada pada pimpinan Satker.

Pelatihan maupun bimbingan teknis kepada pilot drone yang dilaksanakan di KLHK belum cukup tanggap memasukkan pengetahuan aeronautika yang disyaratkan sehingga sertifikat pelatihannya belum dapat digunakan untuk sertifikasi pilot drone di Kemenhub melalui aplikasi SIDOPI.

\section{KESIMPULAN DAN SARAN}

Dari catatan yang ditemui selama penelitian maka beberapa hal penting dapat disimpulkan terhadap implementasi kebijakan pengoperasian PUTA di KLHK yang ditinjau dari isi kebijakan dan lingkungan implementasi.

\section{A. Kesimpulan}

Kesimpulan diungkapkan dari sisi isi kebijakan dan lingkungan implementasi.
Berdasarkan faktor isi kebijakan diperoleh dua catatan yakni: pertama, prosedur perizinan yang harus mendapatkan rekomendasi pengelola kawasan, terutama pada kawasan yang diduga terdapat tindak pidana kehutanan dan lingkungan, tidak sejalan dengan kepentingan KLHK dalam upaya penyelidikan pelanggaran prinsip kelestarian kehutanan dan lingkungan.

Kedua, KLHK belum sampai meregistrasi PUTA dan menyertifikasi pilot drone-nya. Hal ini dapat menyulitkan proses operasi drone di KLHK dan berpotensi melanggar hukum penerbangan.

Sementara simpulan berdasarkan faktor lingkungan implementasi adalah: pertama, KLHK cukup tanggap terhadap kebijakan pengoperasian PUTA dengan menerbitkan peraturan menteri P.16/2018, namun tidak relevan lagi dengan terbitnya PM.37/2020. Sosialisasi hingga peraturan di KLHK belum diterima dengan utuh pada tingkat Satker.

Kedua, upaya-upaya untuk meningkatkan kompetensi telah banyak dilakukan oleh beberapa pihak dengan berbagai bentuk dan melibatkan sumber daya internal maupun eksternal KLHK, namun masih terfokus pada pilot drone dan belum menyasar kepada pimpinan satker sebagai pengambil keputusan. Pelatihan maupun bimbingan teknis kepada pilot drone yang dilaksanakan di KLHK belum cukup untuk menyertifikasi pilot drone.

\section{B. Saran}

Terdapat 5 (lima) hal yang dapat direkomendasikan berdasarkan temuan penelitian ini adalah: pertama, Ditjen Gakkum perlu menjalin dan merancang suatu perjanjian kerja sama dengan pihak yang berwenang (kepolisian) guna dapat melaksanakan beberapa pekerjaan KLHK yang bersifat khusus, misalnya pekerjaan penyelidikan tindak pidana kehutanan dan lingkungan. Sementara Satuan Kerja di daerah perlu menjalin koordinasi dan kerja sama dengan kepolisian di wilayahnya. 
Kedua, Sekretariat Jenderal melalui Pusat Keteknikan perlu merevisi P.16/2018 menyesuaikan Peraturan Menteri Perhubungan PM.37/2020 tentang Pesawat Udara Tanpa Awak dan atau mewujudkan pedoman teknis penggunaan PUTA lingkup KLHK yang dapat menjadi rujukan pengguna PUTA dan pimpinan Satker di KLHK. Sosialisasi peraturan kepada pengguna PUTA lingkup KLHK perlu segera dilakukan dengan melibatkan Pusdiklat-BP2SDM LHK dalam pengembangan kompetensi.

Ketiga, demi legalitas operasi PUTA dan legalitas data yang dihasilkannya dipandang penting seluruh Satker KLHK yang memiliki PUTA untuk memproses legalitas PUTA dan pilot PUTA di KLHK melalui SIDOPI di Kementerian Perhubungan. Keempat, BP2SDM melalui Pusat Diklat SDM KLHK perlu mendesain pengembangan kompetensi aparatur KLHK dalam penggunaan drone secara berjenjang baik pada level pilot drone maupun pimpinan terkait dengan pengoperasian PUTA. Terakhir, Pusat Diklat SDM LHK perlu menyesuaikan kurikulum pengembangan kompetensi bagi pilot drone dengan menambah materi pengetahuan aeronautika yang disyaratkan dalam sertifikasi.

\section{UCAPAN TERIMA KASIH (ACKNOWLEDGEMENT)}

Terima kasih kepada segenap pimpinan Pusat Diklat SDM LHK dan Lembaga Administrasi Negara beserta jajarannya yang telah memfasilitasi kegiatan penelitian dan pembimbingan. Kepada Dr. Ir. Bahdarsyah, M.Pd., dan Yogi Suwarno, S.IP., MA., Ph.D, selaku pembimbing yang telah banyak meluruskan baik pemikiran sejak rencana penelitian maupun hasil penelitian ini kami haturkan banyak terima kasih. Terima kasih kepada Dr. Muhammad Taufiq, D.EA dan Dr. Muhammad Aswad, M.Si yang telah memberikan penajaman dan arahan yang sangat berarti untuk tulisan ini saat mengevaluasi pada ujian tertutup.
Kepada Dr.Ir. Rhuanda Agung Sugardiman, $\mathrm{M}, \mathrm{Sc}$ - Senior yang membidangi Data Spasial dan Pengingeraan Jauh yang saat penelitian menjabat sebagai Direktur Jenderal Pengendalian Perubahan Iklim, Kementerian LHK yang telah memberikan informasi terkait penggunaan drone di KLHK kami sampaikan terima kasih. Kepada Kepala Pusat Keteknikan Kehutanan dan Lingkungan, Kementerian LHK-Ir. Gatot Subiantoro, M,Sc- beserta staf kami ucapkan terima kasih atas informasi dan dukungan untuk tulisan ini. Kepada Kepala Balai Taman Nasional Bantimurung Bulusaraung - Ir. Yusak Mangatan beserta jajarannya kami ucapkan terima kasih atas izin dan dukungan selama di lapangan.

Kepada Kolonel Penerbang Agung Sasongkojati, M.A.Sc., M.S.S., - Paban II Puan Spotdirga KSAU-Ketua Drone Federasi Aero Sport Indonesia (FASI), yang banyak memberikan informasi tentang proses kebijakan drone kami ucapkan terima kasih. Kepada Pak Iyan Andri dari Ditjen Perhubungan Udara Kementerian Perhubungan, dan Pak Muji Subagio dari AirNav kami haturkan terima kasih atas diskusi dan informasi yang sangat berharga. Juga kepada informan lain yang kami temui untuk memperkaya tulisan ini yang tidak dapat kami sebutkan satu per satu, kami ucapkan terima kasih.

Terima kasih kepada Dr. Ir. Hikmat Ramdan, S.Hut., M.Si., IPU-Dosen Sekolah Ilmu \& Teknologi ITB dan Zulfikar Mardiyadi, S.Hut., Msi-Dosen Universitas Papua, founder Indonesia Mapping Community (IMC), yang telah memberikan pencerahan akademis dan teknis terkait penggunaan drone.

\section{DAFTAR PUSTAKA}

Andyono, G. (2020). Balai TN Way Kambas memanfaatkan drone untuk konservasi. Http:// Ksdae.Menlhk.Go.Id/Berita. http://ksdae. menlhk.go.id/berita/2748/balai-tn-way-kambasmanfaatkan-drone-untuk-konservasi.html. 
Edward III, G. C. (1984). Public Policy Implementing (Edited ed.). London-England: Jai Press Inc.

Eko Prasetyo, Y. (2020, December 17). Implementasi Kebijakan Tentang Pengendalian Pengoperasian Pesawat Udara Tanpa Awak di Kabupaten Ponorogo (Peraturan Menteri Perhubungan NO. 90 Tahun 2015). Ponorogo: Repository Muhammadiyah University of Ponorogo.

FDS. (2019). Drone dalam Forestry atau Pekerjaan Kehutanan. Diunduh tanggal 5 Juli 2020 dari Https://Www.Fulldronesolutions.com.

Grindle, M. S. (1980). Politics and Policy Implementation in the Third World. New Jersey: Princeton Legacy Library.

Hodgson, J.C., Koh, L.P. (2016). Best practice for minimising unmanned aerial vehicle disturbance to wildlife in biological field research. $J$. Curr Biol.26(10):R404-5. doi: 10.1016/j. cub.2016.04.001.

Hutauruk, F. (2021). Pembahasan Draft Pedoman Teknis Penggunaan Pesawat Udara Tanpa Awak/ Drone Lingkup Kementerian Lingkungan Hidup dan Kehutanan. Jakarta: Pusat Keteknikan Kehutanan dan Lingkungan.

Kardasz, P., Doskocz, J., Hejduk, M., Wiejkut, P., \& Zarzycki, H. (2016). Journal of Civil \& Environmental Engineering Drones and Possibilities of Their Using. J Civil Environ Eng, 6(3), 1-7. https://doi.org/10.4172/2165784X.1000233.

KLHK. (2018). Status Hutan \& Kehutanan Indonesia 2018. Kementerian Lingkungan Hidup dan Kehutanan.

KLHK. (2020). Rencana Strategis Tahun 2020-2024. Kementerian Lingkungan Hidup dan Kehutanan.

Peraturan Menteri Perhubungan Nomor PM 37 Tahun 2020. Pengoperasian Pesawat Udara Tanpa Awak Di Ruang Udara Yang Dilayani Indonesia, (2020).

Pradana, R. (2019). Laporan Pencermatan Kembali Regulasi Penggunaan Drone Untuk Aktivitas Wisata di Dalam Kawasan Taman Nasional Komodo. Labuan Bajo: Balai Taman Nasional Komodo.

Purbawiyatna, A., Kartodihardjo, H., Alikodra, H. S., \& Prasetyo, L. B. (2011). Analisis Kelestarian Pengelolaan Hutan Rakyat di Kawasan Berfungsi Lindung. Jurnal Pengelolaan Sumberdaya Alam dan Lingkungan, 1(2), 84. https://doi. org/10.29244/jpsl.1.2.84
Pustek. (2020). Data Base Drone. Jakarta : Pusat Keteknikan Kehutanan dan LingkunganSekretariat Jenderal-Kementerian Lingkungan Hidup dan Kehutanan.

Putra, A.S., Dedy, Novatiana, R., Zamzani. (2014). Putusan Pengadilan Negeri Meulaboh No.131/ Pid.B/2013/PN.MBO. Meulaboh: Direktori Putusan Mahkamah Agung Republik Indonesia. Diunduh tanggal 20 September 2021 dari https:// putusan3.mahkamahagung.go.id/direktori/ putusan/9f83033d3e85760ff0a628703a233ab1. html.

Sankey, T. T., Leonard, J. M., \& Moore, M. M. (2019). Unmanned Aerial Vehicle - Based Rangeland Monitoring: Examining a Century of Vegetation Changes. Rangeland Ecology and Management, 72(5), 858-863. https://doi.org/10.1016/j. rama.2019.04.002.

Silvika. (2020, December). Pelatihan Penggunaan Drone Untuk Bidang Lingkungan Hidup dan Kehutanan. Silvika.

Syahbani, M. H. (2020). Implementasi Peraturan Pengoperasian Pesawat Tanpa Awak Dengan Aplikasi Berbasis Mobile Phone. Jumanji, 4(1), 31-39.

Trisnanti, M. (2014). Studi mengenai Implementasi Kebijakan Program Layanan Referensi di Perpustakaan Universitas Surabaya. Jurnal Unair, 3(2), 277-291.

Ustidivanissa, L.F; Njatrijani, R; Pramono, A. (2017). Tinjauan Yuridis Pengoperasian Pesawat Tanpa Awak Terhadap Keselamatan Penerbangan Di Wilayah Negara Kesatuan Republik Indonesia (Studi Pada Pt. Uavindo Nusantara, Bandung) | Rinitami Njatrijani, Agus Pramono. Diponegoro Law Jurnal, 6(2), 1-14. https://ejournal3.undip. ac.id/index.php/dlr/article/view/17365/16620

Yoedtadi, M. G. (2019). Penggunaan Drone Pada Peliputan Berita Televisi (Perspektif Wartawan Televisi Terhadap Etika Peliputan Menggunakan Drone). Jurnal Muara Ilmu Sosial, Humaniora, dan Seni, 3(1), 54. https://doi.org/10.24912/ jmishumsen.v3i1.3531. 